\title{
A new method: the usage of natural zeolite as a killer chemical for hydrogen peroxide during the hydrogen peroxide bleaching
}

DOI: 10.35530/IT.070.06.1523

CANDAN AKCA

\section{ABSTRACT - REZUMAT}

\section{A new method: the usage of natural zeolite as a killer chemical for hydrogen peroxide during the hydrogen peroxide bleaching}

In the study, the usage possibility of natural zeolite as hydrogen peroxide killer during the hydrogen peroxide bleaching was investigated. Natural zeolite from Gördes region with $30 \mu \mathrm{m}$ particle size was used during the hydrogen peroxide bleaching of the cotton fabric as a hydrogen peroxide killer agent. ICP-MS elemental analysis of the natural zeolite was performed. Hydrogen peroxide concentration of the bleaching liquor was performed by quantitative analysis. It was seen that natural zeolite is so efficient to decrease in hydrogen peroxide concentration in the bleaching bath. It is thought that natural zeolite can be an alternative to antiperoxide enzymes and the other hydrogen peroxide killers which are commonly used in the industry.

Keywords: natural zeolite, hydrogen peroxide, bleaching, antiperoxide enzyme, peroxide titration, ICP-MS

Metodă nouă: utilizarea zeolitul natural pentru eliminarea chimică a peroxidului de hidrogen în timpul albirii

În acest studiu s-a investigat posibilitatea utilizării zeolitului natural ca agent de eliminare a peroxidului de hidrogen în timpul albirii. Zeolitul natural din regiunea Gördes cu dimensiunea particulelor de $30 \mu \mathrm{m}$ a fost utilizat în timpul albirii cu peroxid de hidrogen a țesăturii de bumbac. A fost efectuată analiza ICP-MS a zeolitului natural. Concentrația de peroxid de hidrogen a flotei de albire a fost determinată prin analiza cantitativă. S-a observat că, zeolitul natural este foarte eficient pentru a scădea concentrația de peroxid de hidrogen în baia de albire. Se consideră că, zeolitul natural poate fi o alternativă la enzimele antiperoxid și la ceilalți agenți de eliminare a peroxidului de hidrogen, care sunt utilizate frecvent în industrie.

Cuvinte-cheie: zeolit natural, peroxid de hidrogen, albire, enzime antiperoxid, titrare cu peroxid de hidrogen, ICP-MS

\section{INTRODUCTION}

Hydrogen peroxide is commonly used in many practices such as bleaching, disinfection and oxidation. Hydrogen peroxide is an attractive oxidizing agent because its reaction products are water and oxygen. The most commonly used bleaching method in textile industry is hydrogen peroxide bleaching because it produces acceptable reaction products toxicologically and environmentally [1-3].

Even though numerous studies on the degradation of the hydrogen peroxide were done, the reaction still could not be figured out completely [4-5]. But the common opinion is that the ionic degradation products of the hydrogen peroxide have bleaching effect and radical degradation products cause damage. Dannacher and Schlenker suggested that the perhydroxyl radical ion has a bleaching effect. Hydrogen peroxide does not have bleaching effect in acidic environment, bleaching can be realized only by means of particular auxiliary products. Especially alkali environment is required for the conventional peroxide bleaching. When the alkali is added to the hydrogen peroxide solution, perhydroxyl anions occur and the bleaching happens. Sodium hydroxide activates hydrogen peroxide. Because $\mathrm{H}^{+}$ion which is needed for $\mathrm{HO}_{2} \cdot$ release neutralizes with the alkali. When activator and stabilizer are added to the environment in hydrogen peroxide, it is possible to realize the process at a lower temperature, at lower $\mathrm{pH}$, in a shorter period and with lower peroxide considerations and in more moderate conditions with more control and without damaging the fabric. Also, the risk of damage of the fabric is reduced by removing the hydrogen peroxide from the environment by means of various chemicals or antiperoxide enzymes quickly in the end of the process, and efficiency and quality of the next dying process is enhanced [5-8].

Zeolite is a mineral which is abundantly found in nature and of which handling is easier and cheaper compared to other minerals. Zeolite mineral is a remarkable mineral due to its high ion exchanging capacity, adsorption capacity and other features and its usage area gets larger every passing day. Today, its main usage areas are contamination control, energy production, agriculture and stock raising, mining and metallurgy, paper industry, health sector, detergent industry, besides, it is thought that its usage area will get larger as a results of the studies carried out in this respect [9].

Due to outstanding characteristics of zeolite which is abundantly found in our country, it is important to 
investigate the usage areas of the zeolite the field of textile finishing and improve the implementation opportunities, in terms of enabling the eco-friendly textile production and turning our rich zeolite reserve into added-value [9].

Finnegan et al. analyzed the degradation of hydrogen peroxide by adding zeolite and sodium citrate to the environment in the process of hydrogen peroxide bleaching in one of the study they performed in 1998. It was reported that the zeolite could not prevent the degradation of the hydrogen peroxide degradation in an alkali environment, besides it accelerated the degradation by interact with hydrogen peroxide. It was suggested that the manganese cations which are a transfer product between manganese ions of the sodium citrate and zeolite helped the movement of the manganese cations towards the zeolite structure. It was also stated that the change of the sodium citrate quantities in the environment changed the manganese -citrate complex quantities [10].

In this study, the effect of the peroxide on the hydrogen peroxide bleaching was examined.

\section{MATERIAL AND METHOD}

In this study, natural zeolite consisting 90\% clinoptilolite, originating from Gördes region, with $30 \mu \mathrm{m}$ particle size was used. Weighing $5 \mathrm{~g}, 139 \mathrm{~g} / \mathrm{m}^{2}$, $100 \%$ cotton raw jersey fabric was used in the process. The process was carried out by using the prescription written below and adopting the process conditions and process graphic (table 1). In this way, the peroxide killer effect of the zeolite was analyzed. The processes were carried out in Termal branded sample dyeing machine.
During the process, hydrogen peroxide quantity in the bath assessed iodometrically with 15 minuteintervals.

\section{Method}

In the stage I, $10 \mathrm{ml}$ bleach flotte whose concentration will be analyzed is acidified with $40 \mathrm{ml}, 10 \%$ sulfuric acid solution $\left(\mathrm{H}_{2} \mathrm{SO}_{4}\right)$ in an erlenmayer. After that, 2-drops of $10 \%$ potassium iodide $(\mathrm{KI})$ solution are added and kept in dark for 5 minutes after 2-3 pieces of ammonium molybdate $\left(\left(\mathrm{NH}_{4}\right)_{6} \mathrm{Mo}_{7} \mathrm{O}_{24}\right.$. $4 \mathrm{H}_{2} \mathrm{O}$ ) particle added. Meanwhile, $\mathrm{H}_{2} \mathrm{O}_{2}$ in the flotte oxidizes an equivalent quantity of iodide $\left(\mathrm{I}^{-}\right)$to molecular iodine $\left(\mathrm{I}_{2}\right)$. In the stage II, the solution remains colorless until the first thiosulphate drops to the bath even though starch is added. However, a dark blueblack color is seen as soon as the thiosulphate is dropped. Until the color is disappeared, $\mathrm{H}_{2} \mathrm{O}_{2}$ concentration in the flotte is calculated by titrating with $0.1 \mathrm{~N}$ sodium thiosulphate solution and based on the thiosulphate quantity spent. Every $1 \mathrm{ml} 0.1 \mathrm{~N}$ sodium thiosulphate solution spent corresponds to 1.7008 $\mathrm{mg} \mathrm{H}_{2} \mathrm{O}_{2}$ and $0.8 \mathrm{mg}$ active oxygen [11].

\section{RESULTS AND DISCUSSION}

When table 3 and figure 1 indicating the peroxide quantity depending on time from different prescriptions are examined, it is seen that the peroxide contraction decreased rapidly during first 15 minutes and the decrease rate in peroxide concentration reduces with the extension of the time. However, the degradation rate of hydrogen peroxide in R3 prescription consisting $\mathrm{NaOH}$ and zeolite along with the hydrogen peroxide in first 15 minutes is higher than the all other prescriptions. In first 15 minutes, a significant part of

Table 1

\begin{tabular}{|c|c|c|c|}
\hline \multicolumn{4}{|c|}{ PROCESS PRESCRIPTIONS AND PROCESS TERMS } \\
\hline Prescription 1 & Prescription 2 & Prescription 3 & Prescription 4 \\
\hline $\begin{array}{l}6 \mathrm{ml} / \mathrm{l} \text { Hydrogen peroxide } \\
2,5 \mathrm{~g} / \mathrm{l} \mathrm{NaOH} \\
\mathrm{pH} 11 \\
\mathrm{FO} 1 / 40 \\
60 \mathrm{~min} \text {. at } 95^{\circ} \mathrm{C}\end{array}$ & $\begin{array}{l}6 \mathrm{ml} / \mathrm{l} \mathrm{Hydrogen} \mathrm{peroxide} \\
2,5 \mathrm{~g} / \mathrm{l} \mathrm{NaOH} \\
1 \mathrm{~g} / \mathrm{l} \mathrm{stabilizer} \\
\mathrm{pH} 11 \\
\mathrm{FO} 1 / 40 \\
60 \mathrm{~min} \text {. at } 95^{\circ} \mathrm{C}\end{array}$ & $\begin{array}{l}6 \mathrm{ml} / \mathrm{l} \mathrm{Hydrogen} \mathrm{peroxide} \\
2,5 \mathrm{~g} / \mathrm{l} \mathrm{NaOH} \\
30 \mathrm{~g} / \mathrm{l} \mathrm{Zeolite} \\
\mathrm{pH} 11 \\
\mathrm{FO} 1 / 40 \\
60 \mathrm{~min} \text {. at } 95^{\circ} \mathrm{C}\end{array}$ & $\begin{array}{l}6 \mathrm{ml} / \mathrm{l} \text { Hydrogen peroxide } \\
30 \mathrm{~g} / \mathrm{l} \text { Zeolite } \\
\mathrm{pH} 6 \\
\mathrm{FO} 1 / 40 \\
60 \mathrm{~min} \text {. at } 95^{\circ} \mathrm{C}\end{array}$ \\
\hline \multicolumn{4}{|c|}{ Following Processes } \\
\hline \multicolumn{4}{|c|}{$\begin{array}{l}10 \mathrm{~min} \text {. rinse at } 95^{\circ} \mathrm{C} \\
10 \mathrm{~min} \text {. rinse at } 95^{\circ} \mathrm{C} \\
5 \mathrm{~min} \text {. cold rinse }\end{array}$} \\
\hline
\end{tabular}

Table 2

\begin{tabular}{|c|c|c|c|c|c|c|c|c|c|c|c|}
\hline \multicolumn{12}{|c|}{ ICP-MS ELEMENTAL ANALYSIS RESULTS OF THE NATURAL ZEOLITE } \\
\hline & $\begin{array}{c}\mathrm{Pb} \\
\mathrm{mg} / 10 \mathrm{~g}\end{array}$ & $\begin{array}{c}\mathrm{Ca} \\
\mathrm{mg} / 10 \mathrm{~g}\end{array}$ & $\begin{array}{c}\mathrm{Mn} \\
\mathrm{mg} / 10 \mathrm{~g}\end{array}$ & $\begin{array}{c}\mathrm{Ag} \\
\mathrm{mg} / 10 \mathrm{~g}\end{array}$ & $\begin{array}{c}\mathrm{Zn} \\
\mathrm{mg} / 10 \mathrm{~g}\end{array}$ & $\begin{array}{c}\mathrm{Cu} \\
\mathrm{mg} / \mathrm{g}\end{array}$ & $\begin{array}{c}\mathrm{Na} \\
\mathrm{mg} / 10 \mathrm{~g}\end{array}$ & $\begin{array}{c}\mathrm{Fe} \\
\mathrm{mg} / 10 \mathrm{~g}\end{array}$ & $\begin{array}{c}\mathrm{Mg} \\
\mathrm{mg} / 10 \mathrm{~g}\end{array}$ & $\begin{array}{c}\mathrm{Al} \\
\mathrm{mg} / 10 \mathrm{~g}\end{array}$ & $\begin{array}{c}\mathrm{K} \\
\mathrm{mg} / 10 \mathrm{~g}\end{array}$ \\
\hline $\begin{array}{l}\text { Natural } \\
\text { zeolite }\end{array}$ & 0,57 & 89,07 & 3,89 & - & - & - & 20,85 & 134,59 & 72,52 & 539,84 & 300,76 \\
\hline
\end{tabular}


THE CHANGE OF THE HYDROGEN PEROXIDE CONCENTRATIONS

\begin{tabular}{|c|c|c|c|c|}
\hline $\begin{array}{c}\text { Time } \\
\text { (min) }\end{array}$ & $\begin{array}{c}\mathbf{R}-1 \mathbf{H}_{\mathbf{2}} \mathbf{O}_{\mathbf{2}} \\
(\mathbf{m g})\end{array}$ & $\begin{array}{c}\mathbf{R}-2 \mathbf{H}_{\mathbf{2}} \mathbf{O}_{\mathbf{2}} \\
(\mathbf{m g})\end{array}$ & $\begin{array}{c}\mathbf{R}-3 \mathbf{H}_{\mathbf{2}} \mathbf{O}_{\mathbf{2}} \\
(\mathbf{m g})\end{array}$ & $\begin{array}{c}\mathbf{R}-4 \mathbf{H}_{\mathbf{2}} \mathbf{O}_{\mathbf{2}} \\
(\mathbf{m g})\end{array}$ \\
\hline 0 & 29.764 & 29.764 & 29.764 & 29.764 \\
\hline 15 & 16.1576 & 17.008 & 2.5512 & 17.008 \\
\hline 30 & 12.756 & 15.3072 & 1.7008 & 13.6064 \\
\hline 45 & 11.9056 & 12.756 & 1.7008 & 12.756 \\
\hline 60 & 9.3544 & 11.0552 & 1.7008 & 10.2048 \\
\hline
\end{tabular}

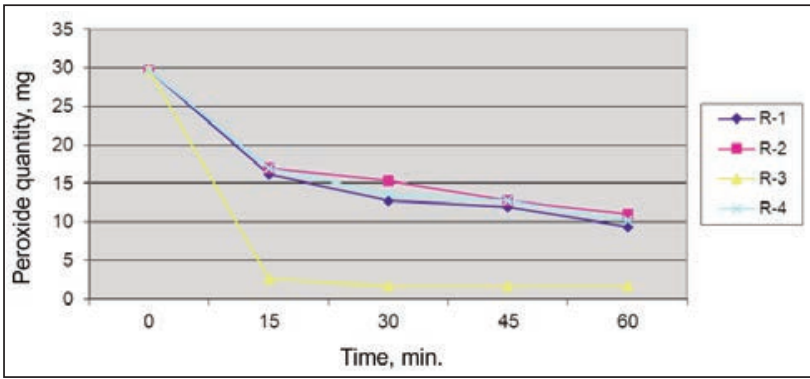

Fig. 1. Peroxide Quantity in the Baths Acquired by means of Peroxide Titration

the peroxide in the bath is degraded in R3 prescription. The degradation rates and characteristics of $\mathrm{R} 1$, R2 and R4 prescriptions are quite similar. The most significant difference of $\mathrm{R} 4$ prescription from $\mathrm{R} 3$ is its $\mathrm{pH}$. Alkalinity of the R3 prescription ( $\mathrm{pH} 11)$ accelerates the degradation rate together with zeolite. Degradation rate of peroxide of R4 is lower comparing to R3 prescription, because weak acidic environment $(\mathrm{pH} 6)$ of $\mathrm{R} 4$ enables the stabilization of hydrogen peroxide in spite of zeolite.

Here $\mathrm{H}_{2} \mathrm{O}_{2}$ oxides zeolite with its oxidizing effect and degrades itself, turns into water, on the other hand, the cage structure of zeolite dissolves as a result of oxidizing [12]. Regarding the antiperoxide enzymes and chemicals, it is intended to neutralize $\mathrm{H}_{2} \mathrm{O}_{2}$ as soon as possible in the end of the process in order to protect the cotton fabric from being damaged and eliminate their decreasing effects on dye efficiency, after $\mathrm{H}_{2} \mathrm{O}_{2}$ bleaching.

$\mathrm{H}_{2} \mathrm{O}_{2}$ concentration in the bath was assessed iodimetrically in every 15 minutes and point data are evaluated by means of regression analysis and the curves in the figures $2-5$ were acquired. Due to the fact that the line functions having the highest correlation coefficient was chosen while determining the line expressing the degradation ideally, the lines acquired can be as logarithmic, exponential or polynomial function. This shows that hydrogen peroxide can be dissolved in different ways depending on the process terms and flotte content [13].

$$
\ln \left(C_{t} / C_{0}\right)=-k \cdot t
$$

In this equality, $k$ shows rate constant of the reaction, $C_{0}$ - original concentration of the product reacting, $C_{t}$ - the concentration in the end of the $t$ time.
As a result of applying the data acquired as consequence of the titration to number (1) equality, the functions in figures $2-5$ are obtained and the values at table 3 obtained as a result of these function lines.

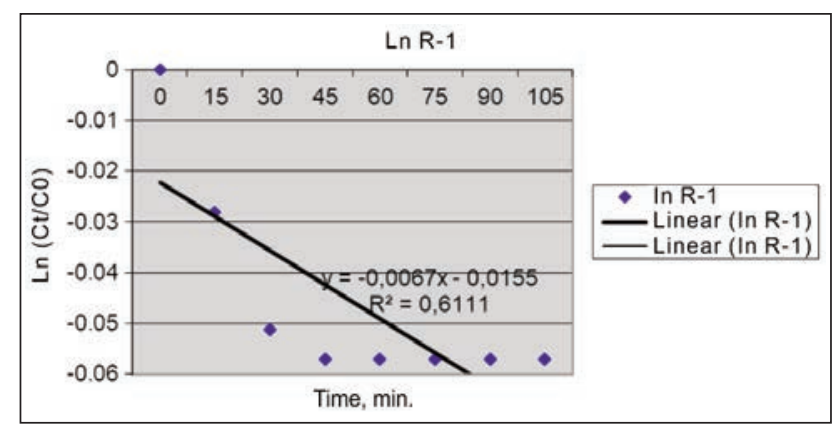

Fig. 2. Determining the reaction rate constant of the degradation of $\mathrm{H}_{2} \mathrm{O}_{2}$ in Prescription 1

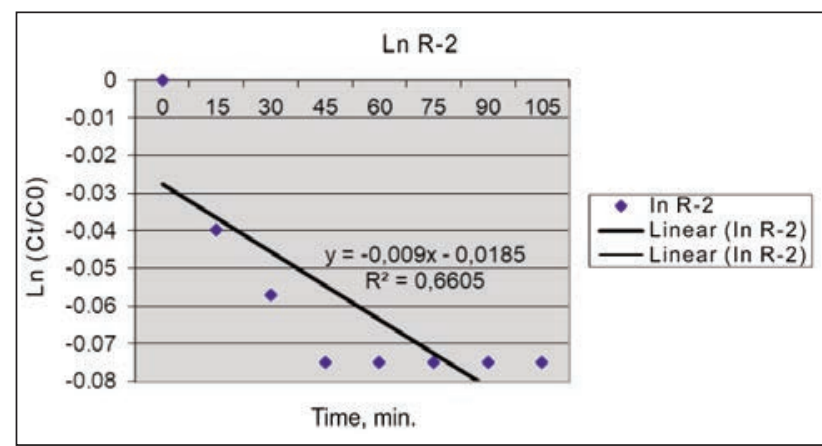

Fig. 3. Determining the reaction rate constant of the degradation of $\mathrm{H}_{2} \mathrm{O}_{2}$ in Prescription 2

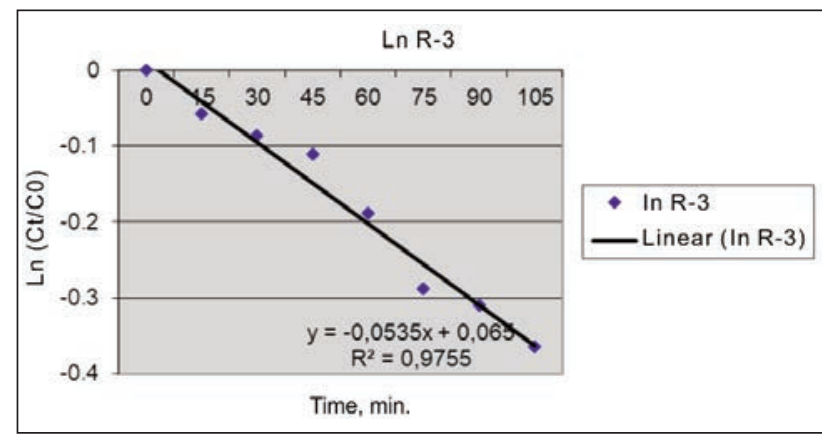

Fig. 4. Determining the reaction rate constant of the degradation of $\mathrm{H}_{2} \mathrm{O}_{2}$ in Prescription 3

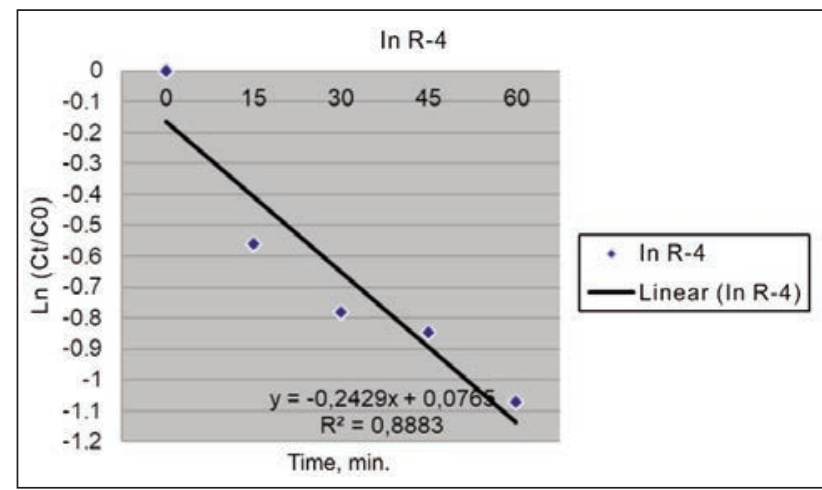

Fig. 5. Determining the reaction rate constant of the degradation of $\mathrm{H}_{2} \mathrm{O}_{2}$ in Prescription 4 
constant was 1.16 in this case when there were $\mathrm{H}_{2} \mathrm{O}_{2}$ and zeolite in flotte, because there was not any alkaREACTION RATE CONSTANTS OF $\mathrm{H}_{2} \mathrm{O}_{2}$ DEGRADATION IN PRESCRIPTIONS

\begin{tabular}{|c|c|c|}
\hline Prescriptions & PH & $\boldsymbol{k}\left(\mathbf{s n}^{-\mathbf{1}}\right) \cdot \mathbf{1 0}^{\mathbf{- 4}}$ \\
\hline 1 & 11 & 1.34 \\
\hline 2 & 11 & 1 \\
\hline 3 & 11 & 7.98 \\
\hline 4 & 6 & 1.16 \\
\hline
\end{tabular}
li addition. When Prescription 3 and 4 were reviewed, it was seen that the rate constant of degradation of $\mathrm{H}_{2} \mathrm{O}_{2}$ decreased rather a lot comparing to the alkali environment when any alkali was not added to the environment.

\section{CONCLUSIONS}

Zeolite is a natural mineral that is water-insoluble. The fact that zeolite is water-insoluble is a big problem during its usage in textile finishing processes

According to the table 4, rate constant in Prescription 2 was calculated as 1 when there were $\mathrm{NaOH}, \mathrm{H}_{2} \mathrm{O}_{2}$ and stabilizer in flotte. In prescription 3 , the degradation of $\mathrm{H}_{2} \mathrm{O}_{2}$ accelerated and rate constant reached 1.34 when there were only $\mathrm{NaOH}$ and $\mathrm{H}_{2} \mathrm{O}_{2}$ in flotte in Prescription 2. There was $\mathrm{NaOH}, \mathrm{H}_{2} \mathrm{O}_{2}$ and zeolite in flotte in Prescription 3. In this case, the degradation of $\mathrm{H}_{2} \mathrm{O}_{2}$ accelerated and rate constant reached 7.98. When Prescription 2 and Prescription 3 were reviewed it was seen that average zeolite addition accelerated the degradation of $\mathrm{H}_{2} \mathrm{O}_{2}$ almost 6 times more. This situation shows us clearly that zeolite can be used as $\mathrm{H}_{2} \mathrm{O}_{2}$ killer in $\mathrm{H}_{2} \mathrm{O}_{2}$ bleaching. When Prescription 4 was reviewed, $\mathrm{pH}$ was 6 and the rate because any homogeneous application cannot be done on the surface of the textile material.

This study shows us that we can use the natural zeolite as hydrogen peroxide killer in hydrogen peroxide bleaching process, however, there is a need of optimization in terms of preparing the prescriptions, and a mechanism design which will have a special place in the machine and which will enable the zeolite to move through flotte without dissolving in bleaching bath.

And use of the natural zeolite as hydrogen peroxide killer in hydrogen peroxide bleaching process is a better alternative because Turkey has a large amount of zeolite reserve.

\section{REFERENCES}

[1] Ahn, B.J., Kondo, R., Sakai, K., Effect of activator on hydrogenperoxidebleaching of White ledger, In: Ind. Chem., 2001, 5(7), 285-291

[2] Brooks, R.E., Moore, S.B., Alkaline hydrogenperoxidebleaching of cellulose, In: Cellulose, 2000, 7, 263-286

[3] Kumbasar, E.P., Körlü, A.E., Can, C., The effects of activator on whiteness and hydrophility during the hydrogen peroxide bleaching, In: Tekstil ve Konfeksiyon, 2011, 1, 50-57

[4] Westbroek, P., Kiekens, P., Electrochemical behaviour of hydrogen peroxide oxidation: kinetics and mechanisms, In: Anayltical electrochemistry in textiles, Woodhead Publishing Limited, Cambridge, 2005, 92-94

[5] Eren, H.A., Aniş., P., Yılmaz, D., Kirişci, Ş., İnkaya, T., Combined used of laccase, ozone, and hydrogen peroxide for cotton bleaching, In: Tekstil ve Konfeksiyon, 2009, 4, 299-303

[6] Rouette, H.K., Letter h", Enyclopedia of textilefinishing, Springer-Verlag, Heidelberg, 2002, 82-86 (cd book)

[7] Karmakar, S.R., Bleaching of Textiles Chemical Technology in the Pre-Treatment Processes of Textiles, Elsevier, Amsterdam, 1999, 170-172

[8] Cai, J.Y., Esans, D.J., Guadine derivatives used as a peroxide activators for bleaching cellulosic textiles, In: Color Technology, 115-118

[9] Özaydın, S., Doğal Klinoptilolitlerin Türkiye'deki Kullanım Olanakları ve Gördes Klinoptilolitlerinin Isıl Özelliklerinin Belirlenmesi Üzerine Bir Araştırma, Ege Üniversitesi, Fen Bilimleri Enstitüsü, Doktora Tezi, 2005

[10] Finnegan, D., Stock, K., Dunn, L., Peroxide Bleaching Using Zeolites Part I: Peroxide Decomposition, In: Appita Journal, 1998, 51, 219-223

[11] Bilgin, E., Selüloz Esaslı Kumaşlarda Ön Terbiye Iş̧/emleri Sırasında Meydana Gelen Kimyasal Zararlar ve Analiz Yöntemleri, Ege Üniversitesi Fen Bilimleri Enstitüsü, Yüksek Lisans Tezi, 2003

[12] Dyhr, K., Sterte J., Effects of Zeolite Addition on the Manganese Catalyzed Decomposition of Hydrogen Peroxide, In: Journal of Porous Materials, 1999, 6, 275-282

[13] Kleinscheck, K.S., Golcer, M., Ribitsch, V. Dolecek, V., An alternative way to monitor $\mathrm{H}_{2} \mathrm{O}_{2}$ decomposition in bleaching solutions, In: Textile Res. J., 1998, 68, 5, 320-326

\section{Authors:}

\section{CANDAN AKCA}

Celal Bayar University, Salihli Vocational School, Textile Technology Department, Salihli, Manisa, Turkey

\section{Corresponding author:}

CANDAN AKCA

e-mail: candanakca@yahoo.com 